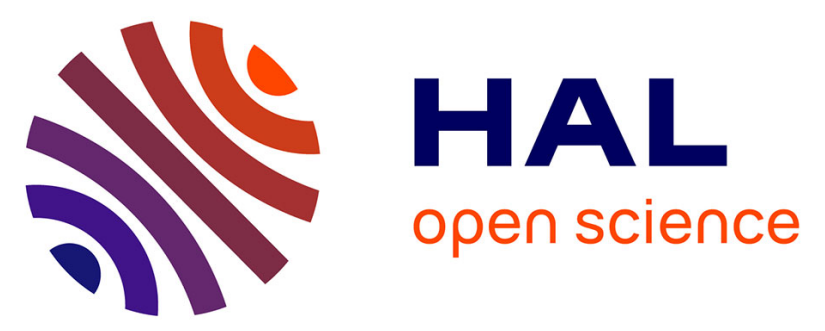

\title{
Harvester ants as ecological engineers for Mediterranean grassland restoration: Impacts on soil and vegetation
} Tania de Almeida, Olivier Blight, François Mesléard, Adeline Bulot, Erick Provost, Thierry Dutoit

\section{- To cite this version:}

Tania de Almeida, Olivier Blight, François Mesléard, Adeline Bulot, Erick Provost, et al.. Harvester ants as ecological engineers for Mediterranean grassland restoration: Impacts on soil and vegetation. Biological Conservation, 2020, 245, pp.108547. 10.1016/j.biocon.2020.108547 . hal-02611640

\section{HAL Id: hal-02611640}

https://institut-agro-rennes-angers.hal.science/hal-02611640

Submitted on 19 Nov 2020

HAL is a multi-disciplinary open access archive for the deposit and dissemination of scientific research documents, whether they are published or not. The documents may come from teaching and research institutions in France or abroad, or from public or private research centers.
L'archive ouverte pluridisciplinaire HAL, est destinée au dépôt et à la diffusion de documents scientifiques de niveau recherche, publiés ou non, émanant des établissements d'enseignement et de recherche français ou étrangers, des laboratoires publics ou privés. 


\title{
Harvester ants as ecological engineers for Mediterranean grassland restoration: Impacts on soil and vegetation
}

\author{
Tania De Almeida ${ }^{\mathrm{a}, \mathrm{b}, *}$, Olivier Blight ${ }^{\mathrm{a}}$, François Mesléard ${ }^{\mathrm{a}, \mathrm{b}}$, Adeline Bulot ${ }^{\mathrm{c}}$, Erick Provost ${ }^{\mathrm{a}}$, \\ Thierry Dutoit ${ }^{\mathrm{a}}$ \\ a Avignon Université, Aix Marseille Univ, CNRS, IRD, IMBE, Avignon, France \\ ${ }^{\mathrm{b}}$ Institut de Recherche de la Tour du Valat, Le Sambuc, Arles, France \\ ${ }^{\mathrm{c}}$ UMR BAGAP (INRA, Agrocampus Ouest, ESA), 2 rue André Le Nôtre, Angers, France
}

\section{A R T I C L E I N F O}

\section{Keywords:}

Ecosystem engineer

Grassland restoration

Messor barbarus

Plant communities

Soil

\begin{abstract}
A B S T R A C T
Although not widely used, ecosystem engineers represent a promising and sustainable tool in nature-based ecosystem management and restoration. In grassland ecosystems, a few invertebrates that engineer soils have been identified as key species regulating soil nutrients and plant communities' diversity and dynamics. Here, we assessed the role of the harvester ant Messor barbarus, an ecological engineer, in a Mediterranean dry grassland under restoration by characterising its nest environment, particularly the soil and vegetation. We found profound differences in soil physical and chemical variables and plant community structure between nests and antfree patches in the restored grassland. Messor barbarus has improved soil fertility, driven the seed bank towards the reference grassland and significantly increased plant biomass, species richness and micro-local-heterogeneity. As biological filters, $M$. barbarus has driven plant communities towards a new trajectory in the restored site. Ant patches are characterised by mesotrophic species, whereas ant-free patches are dominated by species characteristic of compacted soils. They have accelerated the ecological recovery of Mediterranean dry grassland plants by directly and indirectly facilitating their re-establishment. These results illustrate the potential key role of ants as ecological engineers for the conservation and restoration of Mediterranean grasslands.
\end{abstract}

\section{Introduction}

The well-known effects of ecosystem engineers make them particularly useful in achieving conservation or restoration targets: managing one or a few species can influence community diversity and/or ecosystem functioning. Although still not widely used, ecosystem engineers represent a promising and sustainable tool in nature-based ecosystem management and restoration (Bergen et al., 2001). Terrestrial ecosystem engineers (Jones et al., 1997) play important roles in controlling major ecological functions, such as the dynamics of soil organic matter, mineral nutrients and biological population regulation (Wills and Landis, 2018). These organisms directly or indirectly modulate the availability of resources to other species, by causing physical state changes in biotic and abiotic materials (Jones et al., 1997), and can contribute to the resilience of ecosystems after disturbances (Peterson et al., 1998). They are expected to accelerate ecological recovery by reinstating ecosystem functions after species declines (Manning et al., 2015) and by facilitating the re-establishment of other threatened species.
In grassland ecosystems, a few invertebrates that engineer soils, such as ants or earthworms, have been identified as key species regulating soil nutrients and plant community diversity and dynamics (Eisenhauer et al., 2009; Wills and Landis, 2018). These organisms build organomineral structures with specific physical, chemical and microbiological properties (Jouquet et al., 2006), engineered patches often therefore considered as "islets" because of their uncommon diversity and quantity of soil organisms and plants (Lavelle et al., 1997).

Ants are "bioturbator agents" influencing soil structure through the production of galleries and the translocation of soil aggregates (Bottinelli et al., 2015; Cammeraat and Risch, 2008). They not only change soil physical and chemical properties such as soil water, nutrient content, $\mathrm{pH}$ (FarjiBrener and Werenkraut, 2015; Folgarait, 1998; Frouz and Jilková, 2008), but also affect plant communities (Azcárate and Peco, 2006; Christian, 2001). In terrestrial ecosystems, ants are considered a seed disperser (Wills and Landis, 2018). They also transport seeds to good establishment sites (Hanzawa et al., 1988), reduce seed predation (Ness and Morin, 2008) and competition with the parent plant. In the Mediterranean region, species from the Messor genius are key in many ecological functions such as soil

\footnotetext{
* Corresponding author at: Avignon Université, Aix Marseille Univ, CNRS, IRD, IMBE, Avignon, France.

E-mail address: tania.dealmeida@imbe.fr (T. De Almeida).
} 
structuration or seed dispersal in dry grasslands (Azcárate and Peco, 2007; Bulot et al., 2016). Although they may decrease seed germination by direct predation (Schöning et al., 2004), they also play a key dispersal role when they lose seeds in suitable conditions for germination on the way to the nest (Wolff and Debussche, 1999) or when they deposit them in refuse piles, increasing seedlings recruitment (Azcárate and Peco, 2007). This seed dispersal that is not mediated by any particular seed structure is known as diszoochory (Arnan et al., 2010). Among Messor species, M. barbarus is probably the most common and numerically dominant in western Mediterranean grasslands (Lebas et al., 2016). Messor barbarus is a polymorphic species living in monogynous colonies of about 8000 individuals (Cerdan, 1989). It builds nests composed of a dense network of galleries and interconnected chambers that can reach five meters deep. Usually, colonies reach a stable size at approximately the age of five (Gordon, 1995). Messor barbarus makes permanent and temporary trails with length ranges from 1 to $30 \mathrm{~m}$ (Cerdan, 1989). Previous studies reported their roles on seed redistribution, with in particular an increase in seed density and seed bank species richness in the refuse piles located on the top of the nest (Azcárate and Peco, 2007; Bulot et al., 2016). Other studies reported their roles in changes of soil physical and chemical properties (Azcárate and Peco, 2007; Martín-Perea et al., 2019), especially with an increase in nutrient content, especially potassium, organic matter and $\mathrm{pH}$. As such, referring to Jones et al. (1994), M. barbarus can be considered as an ecosystem engineer in Mediterranean grasslands.

Mediterranean dry grasslands are primary targets of conservation and ecological restoration programs (Buisson and Dutoit, 2006; Janišová et al., 2011). Indeed, considered as biodiversity hot spots, they have been not only reduced in area but also in habitat quality and biodiversity since the 20th century changes in land use (Saunders et al., 1991). Considering their key function, harvester ants may be good ecological engineer candidates to restore grassland vegetation and soil, two ecosystem components key to successful ecological restoration (Ruiz-Jaen and Aide, 2005; Wortley et al., 2013). Ants are used as bioindicators for the evaluation of restoration success (Andersen et al., 2002; Fagan et al., 2010), or are the target of the restoration (Gibb and Cunningham, 2013) but their biological engineering potential to restore degraded grasslands has not been exploited yet.

The objective of our study was to evaluate the role of an ecosystem engineer in the restoration of an ecosystem after its degradation. In 2009, 5.5 ha of the plain of La Crau (south-eastern France; Appendix A), a natural reserve, was heavily polluted by an oil leak. Two years later, after the excavation and removal of all the polluted soil, 72,000 tons of a similar soil were transferred from a nearby active quarry already expanding before the accident (Appendix A) (see Bulot et al., 2014b). This highly valuable grassland (Devaux et al., 1983) has been sharply reduced in its area from 50,000 to 11,500 ha since the 1960 s (Buisson and Dutoit, 2006). This ecosystem is a priority habitat under the EU habitats Directive (EUNIS, 2020).

Seven years after soil replacement, we assessed the role of the harvester ant $M$. barbarus in the restored site, and in the surrounding unaltered dry grassland by characterising soil physico-chemical variables and soil seed banks on the top of the nest, and plant communities in the nest environment compared to grassland off the nest. We specifically hypothesised that $M$. barbarus has (1) modified soil texture by increasing coarse sand content; (2) increased soil chemical parameters (such as available phosphorus, organic carbon and ammonium); (3) increased soil seed bank density and species richness, and (4) increased plant species richness, cover, dissimilarity index and biomass, towards the reference steppe.

\section{Materials \& methods}

\subsection{Study area}

The dry grassland of the plain of la Crau in south-eastern France $\left(43^{\circ} 33^{\prime} \mathrm{N}, 4^{\circ} 52^{\prime} \mathrm{E}\right)$ is considered a "steppe" ecosystem of the Mediterranean basin's rangelands (Devaux et al., 1983; Le Houérou,
2001). Climate is Mediterranean with a $15{ }^{\circ} \mathrm{C}$ mean annual temperature. Mean annual precipitation is $400 \mathrm{~mm}$ to $600 \mathrm{~mm}$ falling in spring and autumn. A strong north-westerly cold wind called "Mistral", blowing at $>50 \mathrm{~km} \cdot \mathrm{h}^{-1}$ for 110 days.year $^{-1}$, induces the dryness of the ecosystem (Devaux et al., 1983). The topography is flat, with siliceous stones covering $>50 \%$ of the soil surface. An impermeable calcareous conglomerate situated $40 \mathrm{~cm}$ below the surface makes the alluvial water table inaccessible and contributes, with the strong wind and low precipitations, to soil drought (Molliex et al., 2013). Over the past several thousand years, itinerant sheep-grazing and prescribed fires have been used for the traditional exploitation of the steppe (Buisson and Dutoit, 2006; Devaux et al., 1983). The plant community is composed of annuals and forbs and is dominated by Brachypodium retusum (Pers.) P. Beauv. and Thymus vulgaris L. Two Messor species cooccur on the site (M. barbarus and M. bouvieri; personal observation), but $M$. barbarus is by far the most abundant.

\subsection{Experimental design}

We selected two study sites, the restored site-a formerly oil degraded site- and a surrounding unaltered dry grassland. At both sites, we randomly selected 10 of the largest $M$. barbarus nests. The selected nests corresponded to class 4 of the Blanco-Moreno et al. (2014) five levels scale. This scale is based on a combination of surface area occupied by the colony, number of entrances, and ant size and behaviour (class 4: nests covering 2-4 $\mathrm{m}^{2}$ with $3-4$ entrances). No class 5 were observed. Taking ant nest size as a proxy of colony age (Tschinkel, 2005), the colonies selected can be assumed to be the first established in the restored site six months after the soil restoration. At both sites, we also defined 10 ant-free patches of $4 \mathrm{~m}^{2}$ with no signs of ant activity (nests, refuse piles or tracks). To avoid any border effects from colony activities, ant-free patches were located at least $5 \mathrm{~m}$ away from the selected nests.

We could not set up a before-after experimental design because $M$. barbarus nest location is unpredictable. Indeed, after their nuptial flight in autumn, mated queens land randomly. At a fine scale, nest location is strongly influenced by the proximity to long-established colonies (Blanco-Moreno et al., 2014) and not by soil properties (e.g. organic carbon, soil strength or aggregate distribution) (Baraibar et al., 2011), leading to a regular or random distribution (Blanco-Moreno et al., 2014). We assumed that if differences were recorded between ant patches and ant-free patches, they were the results of the engineering activity of $M$. barbarus.

\subsection{Soil variables}

We measured, in the first two centimetres of soil both from ant-free patches and under ant refuse piles in February 2018, a set of variables known to strongly influence vegetation (Cano-Ortiz et al., 2014). Part of the soil was frozen for nitrate and ammonium analysis. The rest of the sample was dried and sieved ( $2 \mathrm{~mm}$ sieve) prior to assessing the following without decarbonisation according to standard international methods (Baize, 2018): physico-chemical properties (organic C (organic carbon), total nitrogen, $\mathrm{P}_{2} \mathrm{O}_{5}$ (available phosphorus) (Olsen et al., 1954), $\mathrm{CaO}, \mathrm{MgO}, \mathrm{K}_{2} \mathrm{O}, \mathrm{pH}(\mathrm{KCl}), \mathrm{CEC}$ (Cation Exchange Capacity), C:N ratio, total organic matter) and sizes of fine particles (clay $(<0.002 \mathrm{~mm})$, fine silt $(0.002-0.02 \mathrm{~mm})$, coarse silt $(0.02-0.05 \mathrm{~mm})$, fine sand $(0.05-0.2 \mathrm{~mm})$, coarse sand $(0.2-2 \mathrm{~mm})$ ).

\subsection{Seed bank}

We collected $100 \mathrm{~cm}^{3}$ of the first centimetres of soil under the refuse piles and from the ant-free patches in October 2017. The 40 samples generated (20 from the reference site and 20 from the restored site) were spread on a substrate composed of $1: 3$ compost-vermiculite mix in germination seed trays $(30 \mathrm{~cm} \times 45 \mathrm{~cm})$. All samples were randomly 
placed in a greenhouse for five months from October 2017 to March 2018, with soil moisture kept constant. Germinant seedlings were removed as soon as they were identified to species using Mamarot (2002). Data collected were number of species and number of seedlings.

\subsection{Plant community analyses}

We sampled plant communities in $2 \mathrm{~m} \times 2 \mathrm{~m}\left(4 \mathrm{~m}^{2}\right)$ quadrats placed on each the twenty selected nests (ant patches) and twenty antfree patches in May 2018. In each quadrat, the abundance of each plant species was defined using a modified Braun-Blanquet scale (BraunBlanquet et al., 1952) as follows: 0.2 = represented by a single individual in the $4 \mathrm{~m}^{2}$ quadrat, $1=$ covering $<5 \%, 2=$ covering between $5 \%$ and $25 \%, 3=$ covering between $26 \%$ and $50 \%, 4=$ covering between $51 \%$ and $75 \%$ and finally $5=$ covering $>75 \%$. We visually estimated the percentage of vegetation cover in the same $4 \mathrm{~m}^{2}$ quadrat (Jaunatre et al., 2014).

The micro-local heterogeneity generated by $M$. barbarus activities around the nest (soil excavated by ants and deposited at the surface above ant hills, surrounding refuse piles, ant trails (very clean paths), seed collection by ants, etc.) was assessed by placing three quadrats of $10 \mathrm{~cm} \times 10 \mathrm{~cm}\left(0.01 \mathrm{~m}^{2}\right)$ in each $4 \mathrm{~m}^{2}$ quadrat. In the ant patches, in order to take into account vegetation micro-patterns created by $M$. barbarus, we placed the three quadrats as follows: one on the "green belt" (dense vegetation belt located on the previous year's refuse pile where there is a very high density of seedlings), one on the "soil turned over" (top of nest where the soil is heavily disturbed) and one in an area bearing none of these traces of $M$. barbarus activity. In the ant-free patches, we randomly placed three $0.01 \mathrm{~m}^{2}$ quadrats in each $4 \mathrm{~m}^{2}$ quadrat and counted all plants therein in May 2018, when most of the seedlings could be identified. Then for each of the 40 patches, a microlocal heterogeneity index based on the average of three Bray-Curtis index distances - a dissimilarity index varying between 0 and 1: 0 for similar communities and 1 for distinct communities - was calculated between the three $0.01 \mathrm{~m}^{2}$ quadrats.

Finally, we measured above-ground plant biomass in $50 \mathrm{~cm} \times 50 \mathrm{~cm}\left(0.25 \mathrm{~m}^{2}\right)$ quadrats placed on the "green belt" in the ant patches and randomly in the ant-free patches. In each quadrat, we cut the vegetation at ground level during the productivity peak in June 2018. Each sample was then oven-dried at $40{ }^{\circ} \mathrm{C}$ up to constant weight.

\subsection{Nest density}

We estimated $M$. barbarus nest densities in autumn 2017 by counting the number of nests in six quadrats of $400 \mathrm{~m}^{2}$ randomly distributed at both sites.

\subsection{Statistical analyses}

Prior to statistical analysis, all data distributions were examined using the Shapiro-Wilk test of normality. When data were not normally distributed, they were log-transformed. GLMs with Gaussian distribution were computed to study patch type and site effects and their interaction on soil physico-chemical variables, seed bank (seed density and species richness) and plant community characteristics (species richness, vegetation cover, micro-local heterogeneity and above-ground plant biomass). A GLM with gamma distribution was applied to evaluate patch type and site effects and their interaction on soil variables that violated the assumption of a normal distribution. Models were followed by Tukey HSD post-hoc tests using the package "multcomp" (Hothorn et al., 2016). Significance thresholds for post hoc analyses were set at $P<0.05$. For both site, effect sizes - the Cohen's d index with $95 \%$ confidence intervals for each variable (Cohen, 1992) - were calculated using the package "effsize" (Torchiano, 2019). The magnitude is assessed using the scale provided by Cohen (1992) as follow: $|\mathrm{d}|<0.2$ "negligible", $|\mathrm{d}|<0.5$ "small", $|\mathrm{d}|<0.8$ "medium", $|\mathrm{d}|>0.8$ "large". A positive Cohen's $\mathrm{d}$ indicates a higher value of the response variable in ant patches than in ant-free patches.

Changes in seed bank composition were visualised via Non-metric Multidimensional Scaling (NMDS) based on the Bray-Curtis dissimilarity index to ordinate the characteristics of plant communities (composition and abundance). Differences in seed bank composition were tested by permutation multivariate analysis using the Adonis function.

A redundancy analysis (RDA) was performed to evaluate the influence of six physico-chemical soil variables on plant community composition. From a preliminary RDA analysis including the 19 soil variables measured, the six variables contributing most to the RDA axes were selected. RDA and NMDS analyses and illustrations were performed using the package "vegan" (Oksanen et al., 2016).

A Generalized Linear Model (GLM) with quasi-Poisson distribution was used to compare nest densities between the reference steppe and the restored site. All statistical analyses were performed using the $\mathrm{R}$ software version 1.0.44 (R Development Core Team, 2011).

\section{Results}

\subsection{Soil variables}

In the restored site, clay and coarse sand content were respectively lower and higher in the ant patches than in the ant-free patches (respectively: $\mathrm{z}=-6.76, P<0.001 ; \mathrm{z}=4.89, \mathrm{P}<0.001$; Appendix $\mathrm{B}$ ). We found a large negative effect size of ants on clay content (Cohen's $\mathrm{d}=-2.66 \pm 1.29)$ and a large positive effect size on coarse sand content (Cohen's $d=2.88 \pm 1.34$ ) (Appendix C). In the reference steppe, we found no significant differences in fine particles between ant and ant-free patches (Appendix B). No significant difference was found in fine silt, coarse silt and fine sand content at either site (Appendix B).

In the restored site, $\mathrm{CEC}, \mathrm{pH}(\mathrm{KCl}), \mathrm{K}_{2} \mathrm{O}, \mathrm{MgO}, \mathrm{CaO}$ and total nitrogen content were significantly higher in ant patches than in ant-free patches (Appendix B) with a large positive effect size (Appendix C). In the reference steppe, there were no significant differences in these variables, except for the $\mathrm{C}: \mathrm{N}$ ratio, which was significantly higher in ant than in ant-free patches. In both sites, ammonium, nitrate, available phosphorus, organic carbon content and total organic matter (Appendix B) were significantly higher in ant patches with a large positive effect size (Appendix C).

\subsection{Seed bank}

The NMDS ordination (stress $=0.18$ ) discriminated on axis 1 the restored site seed banks from those of the reference steppe (Fig. 1). In the restored site, seed bank composition and abundance differed between soil under refuse piles and from ant-free patches $(P<0.01)$. Soil samples collected under refuse piles were characterised by Crepis sancta (L.) Bornm., Lobularia maritima (L.) Desv. and Logfia gallica (L.) Cross. \& Germ., whereas the ant-free patches were characterised by species like Erodium cicutarium (L.) L'Hér. and Filago pygmea L. (Fig. 1). In contrast, the reference steppe seed banks of ant and ant-free patches were not discriminated by NMDS ordination $(P=.13)$; both were characterised by species such as Brachypodium distachyon (L.) P.Beauv., Lysimachia linum-stellatum L. or Linum trigynum L. The composition of the seed bank in the restored site ant patches was significantly different from the compositions in the three other modalities ( $\mathrm{P}<0.01$; Fig. 1).

Both species richness and density were significantly lower in seed banks from ant-free patches in the restored site than from the three other modalities, which did not differ significantly from each other (Table 1). In the restored site, we found a large positive effect size of ants on both species richness (Cohen's $d=2.59 \pm 1.27$ ) and density (Cohen's $d=1.14 \pm 1.01$ ) (Appendix C). 


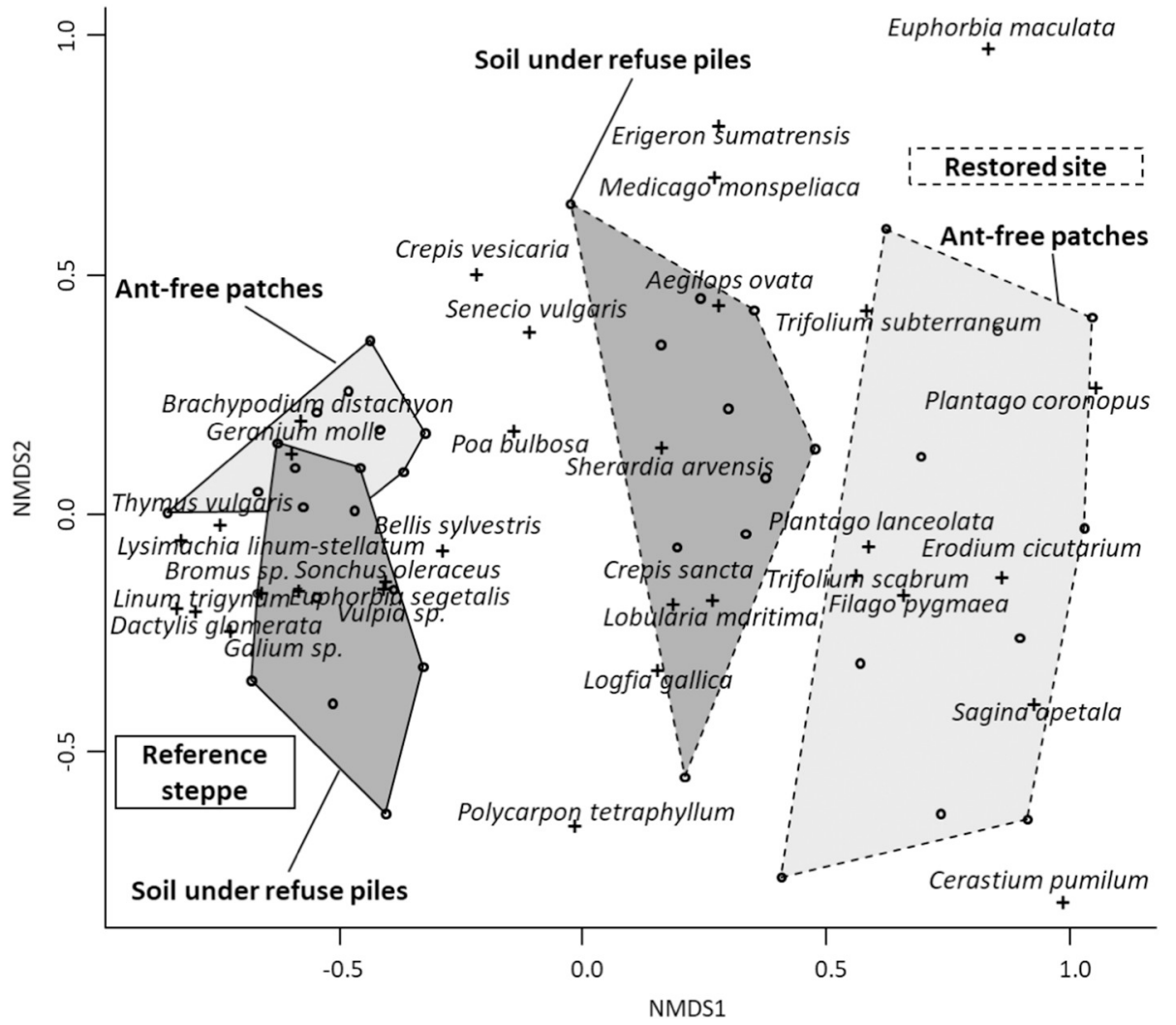

Fig. 1. Non-metric multidimensional scaling (stress $=0.18$ ) performed on the seed bank of the first centimetres of soil $\left(100 \mathrm{~cm}^{3}\right)$ under the refuse piles and in the ant-free patches. The 10 samples of each treatment are grouped in polygons, with dashed lines for the restored site (ant-free patches in light grey and soil under refuse piles in dark grey) and full lines for the reference steppe (ant-free patches in light grey and soil under refuse piles in dark grey). Dots represent the 40 patches and crosses represent the spatial location of each species. For clarity, only the plant species most correlated to the two first axes are shown.

Table 1

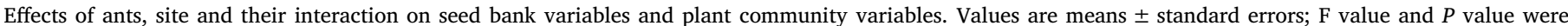

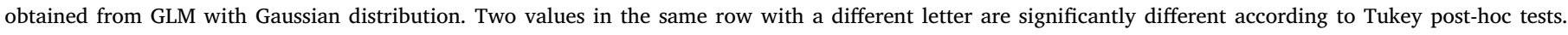
Significance thresholds were set at a risk of $5 \%$.

\begin{tabular}{|c|c|c|c|c|c|c|}
\hline & \multirow[t]{2}{*}{$\mathrm{F}$} & \multirow[t]{2}{*}{$P$-value } & \multicolumn{2}{|c|}{ Restored site } & \multicolumn{2}{|c|}{ Reference steppe } \\
\hline & & & Ant-free patches & Ant patches & Ant-free patches & Ant patches \\
\hline \multicolumn{7}{|l|}{ Seed bank variables } \\
\hline Species richness & & & $9.4 \pm 0.8$ & $17.6 \pm 1.1$ & $16.5 \pm 1.1$ & $14.7 \pm 1.1$ \\
\hline Ants & 9.09 & 0.005 & $\mathrm{a}$ & $\mathrm{b}$ & $\mathrm{b}$ & $\mathrm{b}$ \\
\hline Site & 3.92 & 0.06 & & & & \\
\hline Ants $\times$ site & 22.20 & $<0.001$ & & & & \\
\hline Density $\left(\log \left(\mathrm{dm}^{3}\right)\right)$ & & & $6.1 \pm 0.3$ & $7 \pm 0.1$ & $7.4 \pm 0.1$ & $7.5 \pm 0.2$ \\
\hline Ants & 7.75 & 0.009 & a & b & b & $\mathrm{b}$ \\
\hline Site & 22.82 & $<0.001$ & & & & \\
\hline Ants $\times$ site & 4.75 & 0.04 & & & & \\
\hline \multicolumn{7}{|l|}{ Plant community variables } \\
\hline Specific richness $\left(4 \mathrm{~m}^{2}\right)$ & & & $39 \pm 1.8$ & $45.1 \pm 1.3$ & $36.9 \pm 0.9$ & $40.7 \pm 1.4$ \\
\hline Ants & 12.36 & 0.001 & $\mathrm{a}$ & $\mathrm{b}$ & $\mathrm{a}$ & $a b$ \\
\hline Site & 5.33 & 0.03 & & & & \\
\hline Ants $\times$ site & 0.67 & 0.42 & & & & \\
\hline Vegetation cover $(\%)\left(4 \mathrm{~m}^{2}\right)$ & & & $57 \pm 4.9$ & $65.5 \pm 2.6$ & $69.5 \pm 1.9$ & $74 \pm 2.9$ \\
\hline Ants & 4.35 & 0.04 & $\mathrm{a}$ & $\mathrm{ab}$ & $\mathrm{b}$ & $\mathrm{b}$ \\
\hline Site & 11.36 & 0.002 & & & & \\
\hline Ants $\times$ site & 0.41 & 0.53 & & & & \\
\hline Micro-heterogeneity $\left(0.01 \mathrm{~m}^{2}\right)$ & & & $0.63 \pm 0.03$ & $0.80 \pm 0.02$ & $0.68 \pm 0.03$ & $0.71 \pm 0.02$ \\
\hline Ants & 15.91 & $<0.001$ & $\mathrm{a}$ & $\mathrm{b}$ & $\mathrm{a}$ & $a b$ \\
\hline Site & 0.51 & 0.48 & & & & \\
\hline Ants $\times$ site & 7.23 & 0.008 & & & & \\
\hline Plant biomass $(\log (\mathrm{g}))\left(0.25 \mathrm{~m}^{2}\right)$ & & & $1.1 \pm 0.1$ & $3.0 \pm 0.2$ & $2.3 \pm 0.1$ & $3.2 \pm 0.1$ \\
\hline Ants & 128.85 & $<0.001$ & $\mathrm{a}$ & $\mathrm{b}$ & $\mathrm{c}$ & $\mathrm{b}$ \\
\hline Site & 33.08 & $<0.001$ & & & & \\
\hline Ants $\times$ site & 18.00 & $<0.001$ & & & & \\
\hline
\end{tabular}

\subsection{Plant community characteristics}

At a scale of $4 \mathrm{~m}^{2}$ in the restored site, ant patches had significantly higher plant species richness than ant-free patches $(\mathrm{z}=-3.06$,
$P=0.02$; Cohen's $\mathrm{d}=1.21 \pm 1.02$ ) (Table 1; Appendix C). In the reference steppe, there were no significant differences between ant and ant-free patches $(\mathrm{z}=-1.91, P=0.2)$ (Table 1$)$. There was no significant inter-site difference in plant species richness for either ant 


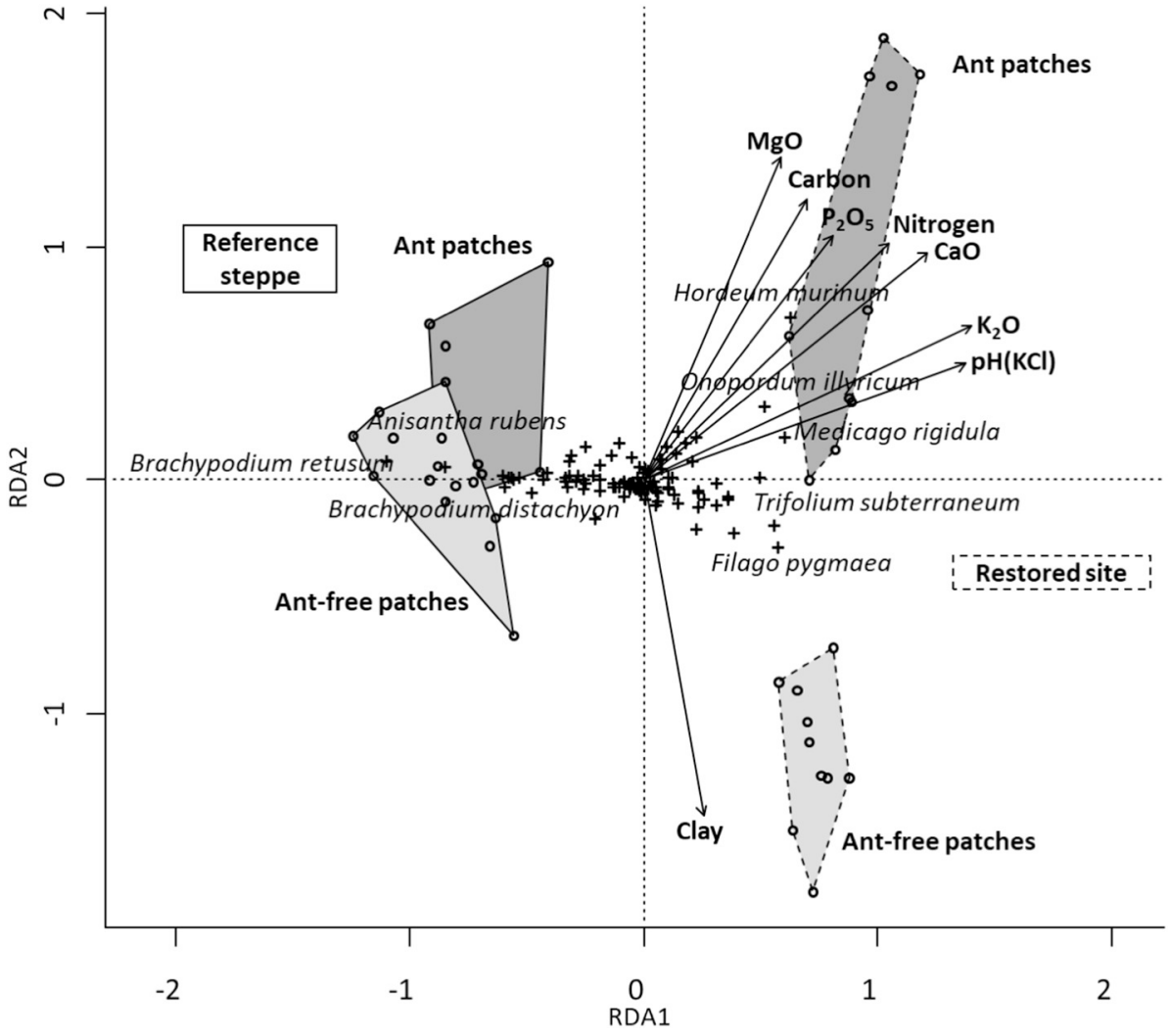

Fig. 2. Redundancy analysis (RDA) showing the vegetation composition correlations with the following soil variables: proportion of clay, $\mathrm{pH}(\mathrm{KCl}), \mathrm{K}_{2} \mathrm{O}, \mathrm{CaO}$, total nitrogen, $\mathrm{P}_{2} \mathrm{O}_{5}$, total organic carbon and $\mathrm{MgO}$. The 10 samples of each treatment were grouped in polygons, with dashed lines for the restored site (antfree patches in light grey and ant patches in dark grey) and full lines for the reference steppe (ant-free patches in light grey and ant patches in dark grey). Dots represent the 40 patches and crosses represent the spatial location of each species. For clarity, only the plant species most correlated to the two first axes are shown. $(\mathrm{z}=-2.21, \mathrm{P}=0.1)$ or ant-free patches $(\mathrm{z}=-1.05, P=0.7)$ (Table 1).

We found no significant difference in vegetation cover between ant and ant-free patches within either site (restored site: $\mathrm{z}=1.93, \mathrm{P}=0.2$; reference steppe: $\mathrm{z}=1.02, \mathrm{P}=0.7$ ) (Table 1 ). Similarly, we found no significant difference in vegetation cover between restored site and reference steppe ant patches $(P=0.2)$. However, vegetation cover was significantly lower in restored site ant-free patches than in reference steppe ant-free patches $(\mathrm{z}=2.84, \mathrm{P}=0.02)$ and ant patches $(\mathrm{z}=3.86$, $P<0.001$ ).

At a scale of $0.01 \mathrm{~m}^{2}$, the interaction term between patch type and sites was significant for the Bray-Curtis distance (Table 1). In the restored site, vegetation heterogeneity was higher in ant patches $(\mathrm{P}<0.001$; Cohen's d = $1.27 \pm 0.57$ ) (Table 1; Appendix C). By contrast, the reference steppe showed no significant differences between ant and ant-free patches $(\mathrm{z}=0.92, P=0.8)$. We found no significant difference in micro-local heterogeneity between the two sites ant patches $(\mathrm{z}=-2.4, P=0.08)$ (Table 1$)$.

At a scale of $0.25 \mathrm{~m}^{2}$, the interaction term between patch type and sites was significant for plant biomass (Table 1). In both sites, plant biomass was significantly higher in ant patches (Table 1) with a large positive effect size (Appendix $C$ ). We found no significant difference in plant biomass between the two sites' ant patches $(\mathrm{z}=1.07, \mathrm{P}=0.7)$.

\subsection{Soil influence on plant communities}

The variation in plant community composition was significantly explained by the first two RDA axes. The first axis (69\% explained, $\mathrm{F}=20.78, \mathrm{P}<0.001$ ) was correlated with soil chemical properties $\mathrm{pH}$ $(\mathrm{KCl})$ and $\mathrm{K}_{2} \mathrm{O}$ content (Fig. 2). These variables discriminated the typical plant community of the reference steppe, dominated by grasses (e.g. B. distachyon, B. retusum, Anisantha rubens (L.) Nevski), from the plant community of the compacted soils of the restored site (e.g. Filago pygmea L., Trifolium subterraneum L.). The second axis (11\% explained, $\mathrm{F}=3.31, \mathrm{P}<0.001)$ discriminated clay content from all the other chemical variables. These variables discriminated plant communities of the restored site ant patches, characterised by more nitrophilous and ruderal species (e.g. Hordeum murinum L., Medicago rigidula (L.) All., Medicago truncatula Gaertn., Onopordum Illyricum L.), from those of the restored site ant-free patches.

\subsection{Nest density}

In autumn 2017, nest density was significantly higher in the restored site $\left(263 \pm 34 . \mathrm{ha}^{-1}\right)$ than in the surrounding reference steppe $\left(167 \pm 19 . \mathrm{ha}^{-1}\right)(t=-2.53, P=0.03)$.

\section{Discussion}

\subsection{Ants in the restored site}

Seven years after soil restoration, we found strong differences between ant and ant-free patches for both soil physical and chemical, and plant community. We recorded higher soil nutrients, seed bank richness and density, plant community richness, plant biomass, and heterogeneity in ant patches highlighting the potential role of M. barbarus in recovering Mediterranean dry grassland. Nest densities quantified in both sites were consistent with the literature (Azcárate and Peco, 2003). In seven years, the $M$. barbarus population has reached high densities and even exceed those of the reference site, which is promising in terms of restoration. Nevertheless, we can expect a decrease in nest density, in the mid-term, due to intraspecific competition (Cushman et al., 1988).

\subsubsection{Effects on the soil compartment}

The strong impact of M. barbarus on the soil compartment supports our first hypothesis that ants, by their engineer's roles, modified soil quality in the restored site. Messor barbarus increased the quantity of coarse sand and decreased the amount of clays in the engineered patches, which may have significantly affected the plant community because changes in soil physical properties can facilitate the 
establishment of plants in a restored site (Li et al., 2010).

Changes we recorded in texture, $\mathrm{pH}$, organic matter and nutrient content (organic $\mathrm{C}$, total nitrogen, $\mathrm{N}-\mathrm{NH}_{4}, \mathrm{~N}-\mathrm{NO}_{3}, \mathrm{P}_{2} \mathrm{O}_{5}, \mathrm{CaO}, \mathrm{MgO}$, $\mathrm{K}_{2} \mathrm{O}$, CEC and C:N ratio) suggest a soil fertility enhancement by Messor barbarus colonies. Both diet and habitat type determine the magnitude of enrichment in ant-engineered patches, granivorous ants contributing more to soil fertility than omnivorous species (Farji-Brener and Werenkraut, 2017). In dry grasslands, harvester ants' nests increase nutrient concentration (MacMahon et al., 2000), probably because of the accumulation of seed debris, ant corpses and other residues of harvester ant activity in refuse piles (MacMahon et al., 2000; Wills and Landis, 2018). In both studied sites, ants had a significant positive impact on ammonium and nitrate content, likely through production of metabolic residues or decomposition of the organic matter accumulated in $M$. barbarus refuse piles. This increases nitrogen content, including the different forms available to plants as ammonium and nitrate (Azcárate and Peco, 2007).

\subsubsection{Effects on vegetation}

Messor barbarus colonies drove seed bank and plant communities towards the reference grassland ecosystem. In the restored site, higher species richness and seed density were recorded in ant patches than in ant-free patches. Seed-harvesting ants play an important role in seed dispersal (Wills and Landis, 2018), particularly in dry ecosystems, where they are present in high densities (MacMahon et al., 2000; Wills and Landis, 2018). Seed-dispersal mutualisms influence seedling recruitment, population dynamics, species distribution, plant-community composition and gene flow (Christian, 2001; Nathan and MullerLandau, 2000). Only seven years after the establishment of colonies, the seed bank composition of restored site ant patches resembled the reference steppe seed bank more than the ant-free seed banks did. Thus, species such as Galium sp. and Vulpia sp., naturally present in the reference steppe, were found in ant patches but not in ant-free patches at the restored site.

Two non-exclusive hypotheses may explain this higher similarity between the ant patch seed banks of the restored site and those of the reference site. First, harvester ants retrieve seeds from the environment and lose, abandon or reject some of them in refuse piles (MacMahon et al., 2000; Sánchez et al., 2006; Bulot et al., 2016). Workers of $M$. barbarus are known to prospect over a mean distance of $30 \mathrm{~m}$ (Cerdan, 1989), but foraging tracks of $>50 \mathrm{~m}$ have been observed (personal observation). Several studied nests were located $<50 \mathrm{~m}$ from the reference steppe, so workers may have prospected in the reference steppe. Second, the nest itself may have acted as a passive trap for seeds due to its coarse texture and/or its height (Brown et al., 2012). Contrary to the reference steppe, with stone cover of $>50 \%$ of the total surface area, the restored site contains very few pebbles. This area being relatively flat, large nests $10 \mathrm{~cm}$ high contribute to the micro-relief, which might be sufficient to trap wind-transported seeds.

Messor barbarus colonies also modified plant communities. They changed community composition and increased plant biomass, species richness and micro-local heterogeneity. As discussed above, the higher proportions of ammonium, nitrates and available phosphorus recorded in ant patches may explain our results. This is consistent with recent findings from meta-analysis that plant biomass and fitness can sometimes be higher in ant nest soils (Farji-Brener and Werenkraut, 2017), probably because of increased nutrients, including ammonium (Lafleur et al., 2005). In grasslands, small-scale disturbances created by ecosystem engineers, such as ant nests and badger mounds, can play a significant role in maintaining species richness and spatial heterogeneity (Platt, 1975), and may contribute to species diversity in restored grasslands that lack the diversity of the native ecosystem (Lane and BassiriRad, 2005).

\subsection{Ants in the reference ecosystem}

Interestingly, $M$. barbarus impacts were more significant in the restored site than in the reference steppe. Two explanations appear tenable. First, the role of ecological engineers like $M$. barbarus is contextdependent and less pronounced in natural or semi-natural ecosystems. Second, because $M$. barbarus has inhabited the reference steppe for thousands of years, a large part of, or even the entire, reference steppe may already have been engineered by $M$. barbarus, including our antfree patches. In some cases, changes in the quality of the organic matter within anthills have been detected 20 years after colony disappearance (Kristiansen and Amelung, 2001). For nests built by Formica montana and Acanthamyops claviger, nutritional differences between mound and surrounding soils were high eight years after site restoration and disappeared after 26 years (Lane and BassiriRad, 2005). Here, the reference steppe soil may have retained "memory" of the ants' engineering after nest abandonment, making their impacts at the patch scale less detectable. This suggests that where engineers have occupied the entire habitat in natural and semi-natural ecosystems, their impacts are expressed at a large scale (Jones et al., 1997).

\subsection{Implications in grassland restoration}

The soil parameters condition the presence of plant populations and communities (Ehrenfeld et al., 2005). In the restored site, the main drivers of the plant community change are the $\mathrm{MgO}$, organic $\mathrm{C}$ and $\mathrm{P}_{2} \mathrm{O}_{5}$ content; essential elements for plant survival and growth (Gurevitch et al., 2002). In western Mediterranean grasslands, changes in their amount may benefit or disadvantage some species (Cano-Ortiz et al., 2014). Although $M$. barbarus has changed the trajectory of plant communities, differences were still significant between the restored site and the reference steppe. The reference plant community was mainly composed of oligotrophic species such as $B$. distachyon, whereas ant patches in the restored site were characterised by more mesotrophic species such as $H$. murinum or $O$. illyricum. Through nest soil modification, ants can act as a biological filter promoting or impeding plant species according to their ecological traits. For example, Lasius flavus provides suitable habitat conditions for the establishment of plant species adapted to poor organic nutrient availability (Ehrle et al., 2019).

The mesotrophic species established in the restored site ant patches only represented part of the species pool present in the seed bank. After nest abandonment (around 10 years), nutrients may well decrease in the soil, allowing steppe plant species such as Galium sp. and Vulpia sp., present in the ant patches' seed bank, to establish populations. This may in turn reduce differences in plant community composition between restored site and reference ecosystem. Monitoring these ant patches after nest abandonment would help to assess the dynamics of their longterm impact and its final implications for the restoration of Mediterranean grasslands.

Interactions between individuals or populations are the basis of the rules for assembling species (Lortie et al., 2004) and play one of the major roles in the functioning and evolution of ecosystems. Given their involvement in many ecological processes such as seed dispersal or soil functioning (nutrient recycling), ant disappearance is a key issue for ecosystem conservation and restoration. Although no Messor species are endangered in South-Western Europe, they can locally disappear because of a pollution such as in La Crau or following the invasion of invasive species (Blight et al., 2014), with major ecological consequences (e.g. Gómez and Oliveras, 2003). Disappearance of key ant species can lead to severe consequences for plants both at a population (Rodriguez-Cabal et al., 2012) and community level (Christian, 2001). In South African shrublands, the disruption of native ant communities by the invasive Argentine ant leads to a disproportionate reduction in 
the densities of large-seeded plants (Christian, 2001). The preservation of mutualistic interactions involving ants is therefore essential for conserving and restoring natural communities.

\section{Conclusion}

Since the soil restoration in 2011, M. barbarus has improved the soil fertility, driving the seed bank towards the reference grassland and significantly increasing plant biomass, species richness and micro-localheterogeneity. They have accelerated the ecological recovery of Mediterranean dry grasslands plants by directly and indirectly facilitating their re-establishment. These results highlight the potential key role of harvester ants as ecological engineers for the conservation and management of these ecosystems. Thus, the recolonization of these habitats by $M$. barbarus seems to be necessary for their restoration. In the case, where it could not naturally colonize (e.g. a site distant from a source population), its reintroduction already tested (Bulot et al., 2014a) can be a valuable tool in ecosystem restoration.

\section{CRediT authorship contribution statement}

T. De Almeida:Conceptualization, Validation, Investigation, Formal analysis, Writing - original draft, Writing - review \& editing.0. Blight:Conceptualization, Validation, Investigation, Formal analysis, Writing - review \& editing.F. Mesléard:Conceptualization, Validation, Investigation, Writing review \& editing.A. Bulot:Conceptualization, Writing - review \& editing.E. Provost:Conceptualization, Writing - review \& editing.T. Dutoit:Conceptualization, Validation, Investigation, Writing - review \& editing.

\section{Declaration of competing interest}

The authors declare that they have no known competing financial interests or personal relationships that could have appeared to influence the work reported in this paper.

\section{Acknowledgements}

This work was supported by Région Sud-PACA (Ph.D. grant) and the Tour Du Valat Research Institute. We thank Hervé Ramone, Perrine Lagarde, Daniel Pavon, Thibaud Torel, Anouk Courtial and JeanFrançois Alignan for field and laboratory assistance. Thanks to Marjorie Sweetko for correcting the English of previous versions of this paper. We also thank three anonymous reviewers for their helpful and constructive comments.

\section{References}

Andersen, A.N., Hoffmann, B.D., Müller, W.J., Griffiths, A.D., 2002. Using ants as bioindicators in land management: simplifying assessment of ant community responses. J. Appl. Ecol. 39, 8-17. https://doi.org/10.1046/j.1365-2664.2002. 00704.x.

Arnan, X., Retana, J., Rodrigo, A., Cerdá, X., 2010. Foraging behaviour of harvesting ants determines seed removal and dispersal. Insect. Soc. 57, 421-430. https://doi.org/10. 1007/s00040-010-0100-7.

Azcárate, F.M., Peco, B., 2003. Spatial patterns of seed predation by harvester ants (Messor Forel) in Mediterranean grassland and scrubland. Insect. Soc. 50, 120-126. https://doi.org/10.1007/s00040-003-0635-y.

Azcárate, F.M., Peco, B., 2006. Effects of seed predation by ants on Mediterranean grassland related to seed size. J. Veg. Sci. 17, 353-360. https://doi.org/10.1658/ 1100-9233(2006)017.

Azcárate, F.M., Peco, B., 2007. Harvester ants (Messor barbarus) as disturbance agents in Mediterranean grasslands. J. Veg. Sci. 18, 103-110. https://doi.org/10.1111/j.1654- 1103.2007.tb02520.x.

Baize, D., 2018. Guide des Analyses en Pédologie: 3e Édition Revue et Augmentée, Editions Q.

Baraibar, B., Torra, J., Westerman, P.R., 2011. Harvester ant (Messor barbarus (L.)) density as related to soil properties, topography and management in semi-arid cereals. Appl. Soil Ecol. 51, 60-65. https://doi.org/10.1016/j.apsoil.2011.08.012.

Bergen, S.D., Bolton, S.M., Fridley, J.L., 2001. Design principles for ecological engineering. Ecol. Eng. 18, 201-210. https://doi.org/10.1016/S0925-8574(01) 00078-7.

Blanco-Moreno, J.M., Westerman, P.R., Atanackovic, V., Torra, J., 2014. The spatial distribution of nests of the harvester ant Messor barbarus in dryland cereals. Insect. Soc. 61, 145-152. https://doi.org/10.1007/s00040-014-0339-5.

Blight, O., Orgeas, J., Torre, F., Provost, E., 2014. Competitive dominance in the organisation of Mediterranean ant communities. Ecol. Entomol. 39, 595-602. https://doi. org/10.1111/een.12137.

Bottinelli, N., Jouquet, P., Capowiez, Y., Podwojewski, P., Grimaldi, M., Peng, X., 2015 Why is the influence of soil macrofauna on soil structure only considered by soil ecologists? Soil Tillage Res. 146, 118-124. https://doi.org/10.1016/j.still.2014.01. 007.

Braun-Blanquet, J., Roussine, N., Nègre, R., Emberger, L., 1952. Les Groupements Végétaux de la France Méditerranéenne. CNRS Edition, Paris.

Brown, G., Scherber, C., Ramos, P., Ebrahim, E.K., 2012. The effects of harvester ant (Messor ebeninus Forel) nests on vegetation and soil properties in a desert dwarf shrub community in north-eastern Arabia. Flora Morphol. Distrib. Funct. Ecol. Plants 207, 503-511. https://doi.org/10.1016/j.flora.2012.06.009.

Buisson, E., Dutoit, T., 2006. Creation of the natural reserve of La Crau: implications for the creation and management of protected areas. J. Environ. Manag. 80, 318-326. https://doi.org/10.1016/j.jenvman.2005.09.013.

Bulot, A., Dutoit, T., Renucci, M., Provost, E., 2014a. A new transplantation protocol for harvester ant queens Messor barbarus (Hymenoptera: Formicidae) to improve the restoration of species-rich plant communities. Myrmecological News 20, 43-52.

Bulot, A., Provost, E., Dutoit, T., 2014b. A comparison of different soil transfer strategies for restoring a Mediterranean steppe after a pipeline leak (La Crau plain, SouthEastern France). Ecol. Eng. 71, 690-702. https://doi.org/10.1016/j.ecoleng.2014.07. 060.

Bulot, A., Provost, E., Dutoit, T., 2016. Refuse pile turnover by harvester ants (Hymenoptera: Formicidae) increases seed density and seedling species richness in dry grasslands. Myrmecological News 23, 91-100. https://doi.org/10.25849/ myrmecol.news_023:091.

Cammeraat, E.L.H., Risch, A.C., 2008. The impact of ants on mineral soil properties and processes at different spatial scales. J. Appl. Entomol. 123, 285-294. https://doi.org/ 10.1111/j.1439-0418.2008.01281.x.

Cano-Ortiz, A., Bioindi, E., Pinto Gomes, C.J., González, Río, Del, S., Cano, E., 2014. Soil and phytosociological characterisation of grasslands in the western Mediterranean. Am. J. Plant Sci. 5, 3213-3240. https://doi.org/10.4236/ajps.2014.521337.

Cerdan, P., 1989. Etude de la Biologie, de L'écologie et du Comportement des Fourmis Moissonneuses du Genre Messor (Hymenoptera, Formicidae) en Crau. Université AixMarseille, pp. 1.

Christian, C.E., 2001. Consequences of a biological invasion reveal the importance of mutualism for plant communities. Nature 413, 635. https://doi.org/10.1038/ 35098093.

Cohen, J., 1992. A power primer. Psychol. Bull. https://doi.org/10.1037/0033-2909.112. 1.155.

Cushman, J.H., Martinsen, G.D., Mazeroll, A.I., 1988. Density- and size-dependent spacing of ant nests: evidence for intraspecific competition. Oecologia 77, 522-525. https://doi.org/10.1007/BF00377268.

Devaux, J.P., Archiloque, A., Borel, L., Bourrelly, M., Louis-Palluel, J., 1983. Notice de la Carte Phyto-Écologique de la Crau (Bouches du Rhône). Biol. Écologie Méditerranéenne.

Ehrenfeld, J.G., Ravit, B., Elgersma, K., 2005. Feedback in the plant-soil system. Annu. Rev. Environ. Resour. 30, 75-115. https://doi.org/10.1146/annurev.energy.30. 050504.144212.

Ehrle, A., Potthast, K., Tischer, A., Trumbore, S.E., Michalzik, B., 2019. Soil properties determine how Lasius flavus impact on topsoil organic matter and nutrient distribution in central Germany. Appl. Soil Ecol. 133, 166-176. https://doi.org/10.1016/j. apsoil.2018.08.021.

Eisenhauer, N., Schuy, M., Butenschoen, O., Scheu, S., 2009. Direct and indirect effects of endogeic earthworms on plant seeds. Pedobiologia (Jena) 52, 151-162. https://doi. org/10.1016/j.pedobi.2008.07.002.

EUNIS-European Nature Information System, 2020. Inf. about EUNIS habitat classif. EU habitats Dir. Annex I habitat types. URL. https://eunis.eea.europa.eu/, Accessed date: 3 March 2020.

Fagan, K.C., Pywell, R.F., Bullock, J.M., Marrs, R.H., 2010. Are ants useful indicators of restoration success in temperate grasslands? Restor. Ecol. 18, 373-379. https://doi. org/10.1111/j.1526-100X.2008.00452.x.

Farji-Brener, A.G., Werenkraut, V., 2015. A meta-analysis of leaf-cutting ant nest effects on soil fertility and plant performance. Ecol. Entomol. 40, 150-158. https://doi.org/ 10.1111/een.12169.

Farji-Brener, A.G., Werenkraut, V., 2017. The effects of ant nests on soil fertility and plant performance: a meta-analysis. J. Anim. Ecol. 86, 866-877. https://doi.org/10.1111/ 1365-2656.12672.

Folgarait, P.J., 1998. Ant biodiversity and its relationship to ecosystem functioning: a review. Biodivers. Conserv. 7, 1221-1244. https://doi.org/10.1023/ A:1008891901953.

Frouz, J., Jilková, V., 2008. The effect of ants on soil properties and processes (Hymenoptera: Formicidae). Myrmecological News 11, 191-199. 
Gibb, H., Cunningham, S.A., 2013. Restoration of trophic structure in an assemblage of omnivores, considering a revegetation chronosequence. J. Appl. Ecol. 50, 449-458. https://doi.org/10.1111/1365-2664.12054.

Gómez, C., Oliveras, J., 2003. Can the Argentine ant (Linepithema humile Mayr) replace native ants in myrmecochory? Acta Oecol. 24, 47-53. https://doi.org/10.1016/ S1146-609X(03)00042-0.

Gordon, D.M., 1995. The development of an ant colony's foraging range. Anim. Behav. 49, 649-659. https://doi.org/10.1016/0003-3472(95)80198-7.

Gurevitch, J., Scheiner, S.M., Fox, G.A., 2002. The Ecology of Plants. Sinauer Associates, Sunderland.

Hanzawa, F.M., Beattie, A.J., Culver, D.C., 1988. Directed dispersal: demographic analysis of an ant-seed mutualism. Am. Nat. 131, 1-13. https://doi.org/10.1086/ 272257.

Hothorn, T., Bretz, F., Westfall, P., Heiberger, R.M., Schuetzenmeister, A., Scheibe, S., Hothorn, M.T., 2016. Package "Multcomp" Simultaneous Inference in General Parametric Models. Project for Statistical Computing, Vienna, Austria.

Janišová, M., Bartha, S., Kiehl, K., Dengler, J., 2011. Advances in the conservation of dry grasslands: introduction to contributions from the seventh european dry grassland meeting. Plant Biosyst. https://doi.org/10.1080/11263504.2011.603895.

Jaunatre, R., Buisson, E., Dutoit, T., 2014. Topsoil removal improves various restoration treatments of a Mediterranean steppe (La Crau, southeast France). Appl. Veg. Sci. 17, 236-245. https://doi.org/10.1111/avsc.12063.

Jones, C.G., Lawton, J.H., Shachak, M., 1994. Organisms as ecosystem engineers. Oikos 69, 373-386. https://doi.org/10.2307/3545850.

Jones, C.G., Lawton, J.H., Shachak, M., 1997. Positive and negative effects of organisms as physical ecosystem engineers. Ecology 78, 1946-1957. https://doi.org/10.1890/ 0012-9658(1997)078[1946:PANEOO]2.0.CO;2.

Jouquet, P., Dauber, J., Lagerlöf, J., Lavelle, P., Lepage, M., 2006. Soil invertebrates as ecosystem engineers: intended and accidental effects on soil and feedback loops. Appl. Soil Ecol. 32, 153-164. https://doi.org/10.1016/j.apsoil.2005.07.004.

Kristiansen, S.M., Amelung, W., 2001. Abandoned anthills of Formica polyctena and soil heterogeneity in a temperate deciduous forest: morphology and organic matter composition. Eur. J. Soil Sci. 52, 355-363. https://doi.org/10.1046/j.1365-2389. 2001.00390.x.

Lafleur, B., Hooper-Bùi, L.M., Mumma, E.P., Geaghan, J.P., 2005. Soil fertility and plant growth in soils from pine forests and plantations: effect of invasive red imported fire ants Solenopsis invicta (Buren). Pedobiologia (Jena) 49, 415-423. https://doi.org/10. 1016/j.pedobi.2005.05.002.

Lane, D.R., BassiriRad, H., 2005. Diminishing effects of ant mounds on soil heterogeneity across a chronosequence of prairie restoration sites. Pedobiologia (Jena) 49, 359-366. https://doi.org/10.1016/j.pedobi.2005.04.003.

Lavelle, P., Bignell, D., Lepage, M., Walters, V., Roger, P., Lavelle, P., 1997. Soil function in a changing world: the role of invertebrate ecosystem engineers. Eur. J. Soil Biol. 33, 159-193.

Le Houérou, H.N., 2001. Biogeography of the arid steppeland north of the Sahara. J. Arid Environ. 48, 103-128. https://doi.org/10.1006/jare.2000.0679.

Lebas, C., Galkowski, C., Blatrix, R., Wegnez, P., 2016. Fourmis d'Europe Occidentale. Delachaux et Niestlé.

Li, X.R., Tian, F., Jia, R.L., Zhang, Z.S., Liu, L.C., 2010. Do biological soil crusts determine vegetation changes in sandy deserts? Implications for managing artificial vegetation. Hydrol. Process. 24, 3621-3630. https://doi.org/10.1002/hyp.7791.

Lortie, C.J., Brooker, R.W., Choler, P., Kikvidze, Z., Michalet, R., Pugnaire, F.I., Callaway, R.M., 2004. Rethinking plant community theory. Oikos 107, 433-438. https://doi. org/10.1111/j.0030-1299.2004.13250.x.

MacMahon, J.A., Mull, J.F., Crist, T.O., 2000. Harvester ants (Pogonomyrmex spp.): their community and ecosystem influences. Annu. Rev. Ecol. Syst. 31, 265-291. https:// doi.org/10.1146/annurev.ecolsys.31.1.265.

Mamarot, J., 2002. Mauvaises Herbes des Cultures. ACTA (Association de coordination technique agricole), Paris.
Manning, A.D., Eldridge, D.J., Jones, C.G., 2015. Policy implications of ecosystem engineering for multiple ecosystem benefits. In: Advances in Reintroduction Biology of Australian and New Zealand Fauna.

Martín-Perea, D., Fesharaki, O., Domingo, M.S., Gamboa, S., Fernández, H.M., 2019. Messor barbarus ants as soil bioturbators: implications for granulometry, mineralogical composition and fossil remains extraction in Somosaguas site (Madrid basin, Spain). Catena 172, 664-677. https://doi.org/10.1016/j.catena.2018.09.018.

Molliex, S., Siame, L.L., Bourlès, D.L., Bellier, O., Braucher, R., Clauzon, G., 2013. Quaternary evolution of a large alluvial fan in a periglacial setting (Crau Plain, SE France) constrained by terrestrial cosmogenic nuclide (10Be). Geomorphology 195, 45-52. https://doi.org/10.1016/j.geomorph.2013.04.025.

Nathan, R., Muller-Landau, H.C., 2000. Spatial patterns of seed dispersal, their determi nants and consequences for recruitment. Trends Ecol. Evol. 15, 278-285. https://doi. org/10.1016/S0169-5347(00)01874-7.

Ness, J.H., Morin, D.F., 2008. Forest edges and landscape history shape interactions between plants, seed-dispersing ants and seed predators. Biol. Conserv. 141, 838-847. https://doi.org/10.1016/j.biocon.2007.12.029.

Oksanen, A.J., Blanchet, F.G., Friendly, M., Kindt, R., Legendre, P., Mcglinn, D., Minchin, P.R., Hara, R.B.O., Simpson, G.L., Solymos, P., Stevens, M.H.H., Szoecs, E., Wagner, H., 2016. Vegan: community ecology package. J. Veg. Sci. 14, 927-930. https://doi. org/10.4135/9781412971874.n145.

Olsen, S.R., Cole, C.V., Watanabe, F.S., Dean, L.A., 1954. Estimation of available phosphorus in soils by extraction with sodium bicarbonate. In: Circular. USDA, Washington (DC, USA), pp. 939.

Peterson, G., Allen, C.R., Holling, C.S., 1998. Ecological resilience, biodiversity, and scale. Ecosystems 1, 6-18. https://doi.org/10.1007/s100219900002.

Platt, J.W., 1975. The colonization and formation of equilibrium plant species associations on badger disturbances in a tall-grass prairie. Ecol. Monogr. 45, 285-305.

R Development Core Team, 2011. R: A language and environment for statistical computing. R Foundation for Statistical Computing, Vienna, Austria.

Rodriguez-Cabal, M.A., Stuble, K.L., Guénard, B., Dunn, R.R., Sanders, N.J., 2012 Disruption of ant-seed dispersal mutualisms by the invasive Asian needle ant (Pachycondyla chinensis). Biol. Invasions 14, 557-565. https://doi.org/10.1007/ s10530-011-0097-5.

Ruiz-Jaen, M.C., Aide, T.M., 2005. Restoration success: how is it being measured? Restor. Ecol. 13, 569-577. https://doi.org/10.1111/j.1526-100X.2005.00072.x.

Sánchez, A.M., Azcárate, F.M., Peco, B., 2006. Effects of harvester ants on seed availability and dispersal of Lavandula stoechas subsp. pedunculata in a Mediterranean grassland-scrubland mosaic. Plant Ecol. 185, 49-56. https://doi.org/10.1007/ s11258-005-9083-2.

Saunders, D.A., Hobbs, R.J., Margules, C.R., 1991. Biological consequences of ecosystem fragmentation : a review. Conserv. Biol. https://doi.org/10.1111/j.1523-1739.1991. tb00384.x.

Schöning, C., Espadaler, X., Hensen, I., Roces, F., 2004. Seed predation of the tussockgrass Stipa tenacissima L. by ants (Messor spp.) in southeastern Spain: the adaptive value of trypanocarpy. J. Arid Environ. 56, 43-61. https://doi.org/10.1016/S01401963(03)00024-7.

Torchiano, M., 2019. Package 'Effsize': Efficient Effect Size Computation. R Packag. Version 0.7.6. doi:https://doi.org/10.5281/zenodo.1480624.

Tschinkel, W.R., 2005. The nest architecture of the ant, Camponotus socius. J. Insect Sci. 5. https://doi.org/10.1093/jis/5.1.9.

Wills, B.D., Landis, D.A., 2018. The role of ants in north temperate grasslands: a review Oecologia 186, 1-16. https://doi.org/10.1007/s00442-017-4007-0.

Wolff, A., Debussche, M., 1999. Ants as seed dispersers in a Mediterranean old-field succession. Oikos 443-452. https://doi.org/10.2307/3546423.

Wortley, L., Hero, J.M., Howes, M., 2013. Evaluating ecological restoration success: a review of the literature. Restor. Ecol. 21, 537-543. https://doi.org/10.1111/rec. 12028. 